УДК 352

DOI https://doi.org/10.32849/2663-5313/2020.3.25

Олег Золотоноша,

канд. юрид. наук, докторант

Дніпропетровсъкого державного університету внутрішніх справ

\title{
ПРАВОВЕ РЕГУЛЮВАННЯ МІСЦЕВИХ ОРГАНІВ ВЛАДИ
}

Досліджено правові засади формування та функиіонування органів місиевого самоврядування в Україні. Проаналізовано джерельну базу місцевих органів влади. Розкрито питання відображення в ключових законах України стосовно місцевого самоврядування сучасної кониепиії місиевого самоврядування. З'ясовано, що в Україні відсутне кониептуальне бачення аж до дезінтеграчії в ході законотворчого процесу, безсистемного напрачювання законодавчих актів, неузгодженості щодо їх розробки та прийняття, різних підходів до визначення статусу, компетениії та відповідальності суб'єктів місиевого самоврядування. Отже, нагальною є потреба збалансувати норми Конституиії України, Хартії та законодавства, що регулює функиіонування місцевого самоврядування. Визначено, що нормативно-правове поле шодо функиіонування та розвитку місиевого самоврядування в Україні складається із регуляторних актів різного рівня. Наголошено, що конщептуальні засади побудови $i$ функиіонування системи місиевого самоврядування визначені $i$ викладені у міжнародних актах, до яких приєдналась $і$ Україна. Це «Всесвітня декларащія місиевого самоврядування» та, як вище зазначено, «Европейська хартія про місиеве самоврядування». Зазначено, що нормативно-правове регулювання місиевих органів влади натепер сформоване, але потребує вдосконалення. Розвиток місиевого самоврядування в Україні має визначатися пошуком рачіональних та ефективних засобів державно-правового впливу на його функиіонування. Наголошено, що адміністративна реформа підвишує дієвість впливу на стан сочіально-економічного розвитку країни та виведення ї із кризи. Одним із найважливіших завдань иієї реформи є формування на місиевому рівні сучасної системи місцевого самоврядування. Адже життєвий рівень населення зрештою залежить від рівня роботи відповідних органів самоврядування та влади. Тому й головний напрям діяльності органів місцевого самоврядування полягає в задоволенні економічних, політичних, сочіальних потреб людини, створенні умов для гармонійного поєднання інтересів людини і суспільства.

Ключові слова: місцеве самоврядування, місцеві органи влади, нормативно-правові акти, правове регулювання, територіальні громади.

Постановка проблеми. На нинішньому етапі розбудови громадянського суспільства, з прийняттям Указу Президента України від 9 грудня 2010 року № $1085 / 2010$ «Про оптимізацію системи центральних органів виконавчої влади», першорядного значення набувають питання вдосконалення адміністративно-правового регулювання діяльності місцевих органів виконавчої влади. Ефективність і дієвість адміністративноправової реформи залежатиме від того, яка система державних органів буде функціонувати на місцях, у яких формах і якими методами вони здійснюватимуть свою діяльність і виконавчо-розпорядчі функції. Ця проблема має не тільки важливе практичне, але й науково-теоретичне значення. Це зумовлено тим, що саме від того, наскільки якісними будуть подальша наукова розробка та обгрунтування реформи місцевих органів виконавчої влади, залежатиме практичне впровадження та пріоритетні засади забезпечення ефективної системи діяль- ності місцевих органів виконавчої влади у сучасних умовах.

Аналіз останніх досліджень і публікацій. У спеціальній літературі розгляд проблем діяльності органів виконавчої влади та органів місцевого самоврядування, їхніх функцій та розмежування повноважень тією чи іншою мірою здійснювався у працях представників вітчизняних наук адміністративного та конституційного права, наук із державного управління, насамперед у роботах В. Б. Авер'янова, О. Ф. Андрійко, М. О. Баймуратова, Ю. П. Битяка, В. І. Борденюка, О. М. Іщенка, В. М. Кампи, А. М. Коваленка, В. К. Колпакова, В. В. Копейчикова, В. В. Кравченка, А. Р. Крусян, П. М. Любченка, Ю. В. Мельника, Н. Р. Нижник, В. Ф. Опришка, О. I. Остапенка, М. П. Орзіха, I. М. Пахомова, Н. Г. Плахотнюк, В. Ф. Погорілка, М. О. Пухтинського, А. О. Селіванова, В. М. Селіванова, О. І. Сушинського, А. Ф. Ткачука, О. Ф. Фрицького, В. В. Цвєткова, В. М. Шаповала, М. К. Якимчука та інших науковців. 
Метою є дослідження правового регулювання діяльності місцевих органів виконавчої влади в Україні шляхом його аналізу.

Виклад основного матеріалу. Правове регулювання суспільних відносин постає потужним засобом впливу держави на суспільні процеси, поведінку, свідомість та діяльність людей. Особливого значення набуває регулювання тих відносин, в які держава зазвичай безпосередньо не втручається. Такими є відносини в системі місцевого самоврядування, що постає як право самостійно та під свою відповідальність вирішувати питання місцевого значення. Правова регламентація відносин органів місцевого самоврядування із громадськістю, формалізуючи права та обов'язки сторін, спрямовуе їхню активність на реалізацію передусім потреб та завдань місцевого самоврядування, а не якихось інших інтересів.

Прийняття Конституції України 1996 р. стало початком нового етапу розвитку суспільства і поставило завдання побудови демократичної, суверенної, правової держави. Конституція України створила правові передумови утвердження місцевого самоврядування в Україні, окреслила загальні засади конституційної моделі територіальної організації влади на місцях, визначила концептуальні напрями діяльності виконавчих органів місцевого самоврядування. У Конституції України зазначено, що «місцеве самоврядування є правом територіальної громади - жителів села чи добровільного об'єднання в сільську громаду жителів кількох сіл, селища та міста самостійно вирішувати питання місцевого значення в межах Конституції і законів України» [5]. Водночас у Законі України «Про місцеве самоврядування в Україні» йдеться про те, що «місцеве самоврядування в Україні - це гарантоване державою право та реальна здатність територіальної громади - жителів села чи добровільного об'єднання в сільську громаду жителів кількох сіл, селища, міста - самостійно або під відповідальність органів та посадових осіб місцевого самоврядування вирішувати питання місцевого значення в межах Конституції і законів України» [9]. У Свропейській Хартії місцевого самоврядування наводиться така дефініція: «місцеве самоврядування означає право і спроможність органів місцевого самоврядування в межах закону здійснювати регулювання та управління суттєвою частиною публічних справ, під власну відповідальність, в інтересах місцевого населення» [3, с. 89].
Спостерігається різниця у концепціях Європейської Хартії та Конституції України, Закону України «Про місцеве самоврядування в Україні», а саме: первинним суб'єктом місцевого самоврядування, основним носієм його функцій і повноважень визначено територіальну громаду села, селища, міста, тобто територіальна громада займає основне місце, а відповідно до Європейської Хартії основоположними є органи місцевого самоврядування.

Натепер Хартія $є$ основним міжнародно-правовим документом для державчленів Ради Європи. Вона містить стандарти організації управління на місцях, які $є$ обов'язковими для держав-членів цієї міжнародної організації. А Україна, яка є членом Ради Європи, взяла на себе зобов'язання здійснювати розробку будьякого законодавства у сфері місцевого самоврядування та регіонального розвитку з обов'язковим урахуванням відповідних правових актів цієї міжнародної організації.

На наш погляд, у нашій державі відсутнє концептуальне бачення аж до дезінтеграції в ході законотворчого процесу, безсистемного напрацювання законодавчих актів, неузгодженості щодо їх розробки та прийняття, різних підходів до визначення статусу, компетенції та відповідальності суб'єктів місцевого самоврядування. Отже, нагальною є потреба збалансувати норми Конституції України, Хартії та законодавства, що регулює функціонування місцевого самоврядування.

Також нормативно-правове поле функціонування та розвиток місцевого самоврядування в Україні складається із регуляторних актів різного рівня: це, як уже зазначалося, Конституція України, яка закладає конституційні основи місцевого самоврядування; закони, що регулюють засади місцевого самоврядування, повноваження органів та посадових осіб: «Про місцеве самоврядування в Україні», «Про статус депутатів місцевих рад», «Про службу в органах місцевого самоврядування», «Про органи самоорганізації населення; закони, що визначають порядок формування органів місцевого самоврядування та обрання голів територіальних громад: «Про вибори депутатів Верховної Ради Автономної Республіки Крим, місцевих рад та сільських, селищних, міських голів», «Про Всеукраїнський та місцеві референдуми»; закони, що $\epsilon$ визначальними для формування ресурсів місцевого самоврядування, порядку формування бюджетів, встановлення податків і зборів тощо: Бюджетний кодекс, Подат- 
ковий кодекс України, «Про розмежування земель державної та комунальної власності»; галузеві нормативні акти, що визначають місце і роль органів та посадових осіб місцевого самоврядування у певних галузях правовідносин: Земельний кодекс, Водний кодекс, «Про основи містобудування», «Про регулювання містобудівної діяльності», «Основи законодавства України про культуру», «Основи законодавства про освіту», «Про охорону здоров'я», «Про охорону навколишнього природного середовища»; нормативні акти Кабінету Міністрів України, міністерств, відомств та інших центральних органів виконавчої влади, що ухвалюються на основі законів України i визначають порядок реалізації певних норм цих законів (перелік актів, що визначають підходи щодо організації тендерних закупівель, встановлення заробітних плат у системі виконавчих органів, виплати субсидій тощо); нормативні акти місцевої ради, що встановлюють особливості здійснення місцевого самоврядування в певній громаді (місцевий статут) та правила і процедури роботи органів місцевого самоврядування (регламент ради та виконкому, положення про комісії ради тощо)

Повертаючись до переліку нормативних актів, слід також звернути увагу на Закон України «Про статус депутатів місцевих рад», що визначає правовий статус депутата сільської, селищної, міської, районної у місті, районної, обласної ради як представника інтересів територіальної громади, виборців свого виборчого округу та рівноправного члена місцевої ради, встановлюе гарантії депутатської діяльності та порядок відкликання депутата місцевої ради [10].

Концептуальні засади побудови і функціонування системи місцевого самоврядування визначені і викладені у міжнародних актах, до яких приєдналась і Україна. Це «Всесвітня декларація місцевого самоврядування» та, як вище зазначено, «Європейська хартія про місцеве самоврядування».

Всесвітню декларацію місцевого самоврядування розроблено Всесвітньою асоціацією місцевого самоврядування. Ця Асоціація називається «Інтернаціональна спілка місцевих влад». Всесвітня декларація місцевого самоврядування прийнята на 27 Міжнародному Конгресі Інтернаціональною Спілкою Місцевих Влад 23-26 вересня 1985 р. [2, с. 65].

У Преамбулі Всесвітньої декларації передовсім обгрунтовується доцільність заснування системи місцевого самоврядування. У ній зазначається, що місцеве самоврядування є найближчим до громадян рівнем управління своїми справами. Підкреслюється, що найкраще саме на місцевому рівні створювати умови для побудови такої гармонійної громади, (тобто територіальних колективів людей), до якої б громадяни відчували свою належність та відповідали за неї. Висловлюється побажання того, щоб Декларація стала для всіх націй стандартом, до якого слід прагнути.

У Всесвітній Декларації наголошується на тому, що місцеве самоврядування передовсім має бути визнане як принцип у Конституції країни або в основному законі про урядові структури держави (ст. 1). Ця ж ідея проводиться і в Європейській хартії, згідно зі ст. 2 якої принцип місцевого самоврядування має бути визнаний у законодавстві країни і по можливості - в іï̈ конституції [2, с. 69].

У Декларації коротко викладається концепція місцевого самоврядування. Місцеве самоврядування, говориться в Декларації, - це право та обов'язок місцевих органів влади регулювати та вести державні справи під свою особисту відповідальність і в інтересах місцевого населення.

Таким чином, розглядаючи деякі нормативно-правові акти поверхнево, а деякі більш ретельніше, слід зазначити, що вони потребують удосконалення.

\section{Висновки}

Динамічний розвиток місцевого самоврядування можливо забезпечити лише через удосконалення відповідного нормативноправового поля, яке має врегульовувати питання організації та діяльності суб'єктів місцевого самоврядування та його забезпечення.

Подальший розвиток місцевого самоврядування в Україні має визначатися пошуком раціональних та ефективних засобів державно-правового впливу на його функціонування. Для підвищення дієвості впливу на стан соціально-економічного розвитку та виведення країни із кризи створена нова сучасна система державного управління шляхом проведення адміністративної реформи. Одним із найважливіших завдань цієї реформи є формування на місцевому рівні сучасної системи місцевого самоврядування. Адже життєвий рівень населення зрештою залежить від рівня роботи відповідних органів самоврядування та влади. Тому й головний напрям діяльності органів місцевого самоврядування полягає в задоволенні економічних, політичних, соціальних потреб людини, створенні умов для гармонійного поєднання інтересів людини і суспільства. 


\section{Список використаних джерел:}

1. Бобровська О. Змістовно-порівняльний аспект публічного адміністрування на місцевому рівні. Публічне адміністрування : теорія та практика. URL: http://nbuv.gov.ua. (дата звернення: 22.02.2020).

2. Всесвітня декларація місцевого самоврядування. Місцеве та регіональне самоврядування України. 1994. Вип. 1/2 (6/7). С. 65-69.

3. Закон про місцеве самоврядування України: науково-практичний коментар / В. I. Батрименко, В. І. Борденюк, Г. В. Виноградова, М. І. Сфремова, I. Крегул. Київ : Книга, 1999. С. 89.

4. Камінська Н. В. Місцеве самоврядування теоретико-історичний і порівняльно- правовий аналіз : навальний посібник. Київ, 2010. 232 с.

5. Конституція України : Закон України від 28 червня 1996 p. URL: http:// zakon4.rada.gov.ua/laws/show/254к/96-вр (дата звернення: 22.02.2020).

6. Концепція реформування місцевого самоврядування та територіальної організації влади в Україні : схвалена розпорядженням Кабінету Міністрів України від 01.04.2014 № 333-р. URL: http://www.rada.gov.ua (дата звернення: 22.02.2020).

7. Організаційні засади функціонування місцевого самоврядування в Україні : / Ю. О. Куц, С. В. Болдирєв, А. Є. Тамм ; за заг. ред. доц. Ю. О. Куца. Харків : Вид-во ХарРІ НАДУ «Магістр», 2004. 180 c.

8. Про добровільне об'єднання територіальних громад : Закон України від 05.02.2015 № 157-VIII. URL: http//www.rada.gov.ua (дата звернення: 12.02.2020)

9. Про місцеве самоврядування в Україні : Закон України від 21.05.1997 № 280/97-ВР. Відомості Верховної Ради Украйни. 1997. № 24. Ст. 170

10. Про статус депутатів місцевих рад : Закон України від 11.07.2002 № 93-IV. URL: http:// www.rada.gov.ua (дата звернення: 12.02.2020).

11. Про ратифікацію Європейської хартії місцевого самоврядування : Закон України від 15.07.1997 № 452/97. URL: http//www.rada.gov.ua (дата звернення: 12.02.2020).

The legal bases of formation and functioning of local self-government bodies in Ukraine are investigated. The source base of local authorities is analyzed. The question of reflection in the key law of Ukraine concerning local self-government is presented the modern concept of local self-government. It has been found that in Ukraine there is no conceptual vision of disintegration during the legislative process, haphazard elaboration of legislative acts, inconsistencies in their elaboration and adoption, different approaches to determining the status, competence and responsibility of local self-government entities. It is therefore urgent to balance the norms of the Constitution of Ukraine, the Charter and the legislation governing the functioning of local self-government. It is determined that the legal and regulatory field of functioning and development of local self-government in Ukraine consists of regulatory acts of different levels. It is outlined that the conceptual foundations for the construction and functioning of the local self-government system are defined and set out in international acts to which Ukraine has also joined. This is the "Universal Declaration of Local Self-Government" and as above the "European Charter for Local Self-Government". It was noted that the regulatory framework of local authorities has been formed to date but needs improvement. The development of local self-government in Ukraine should be determined by the search for rational and effective means of state and legal influence on its functioning. It is emphasized that administrative reform increases the effectiveness of influencing the state of socio-economic development and removing the country from the crisis. One of the most important tasks of this reform is the formation of a modern local government system at the local level. After all, the standard of living of the population depends on the level of work of the respective self-government bodies and authorities. Therefore, the main activity of local self-government bodies is to meet the economic, political and social needs of man, to create conditions for a harmonious combination of interests of man and society.

Key words: local self-government, local authorities, regulatory acts, legal regulation, territorial communities. 